\title{
Is SARS-CoV-2 responsible for relapses of Parkinson's disease?
}

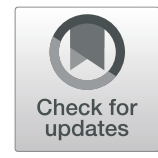

Fulvio A. Scorza ${ }^{1}$ (D) Josef Finsterer ${ }^{2^{*}}$ (D) and Ana C. Fiorini ${ }^{3,4}$ (D)

Keywords: SARS-CoV-2, COVID-19, Parkinson's disease, Complications, Movement disorder

With interest, we read the article by Kamel et al. about a 56-year-old male with Parkinson's disease (PD) in whom worsening of PD was presented as the exclusive clinical manifestation of a SARS-CoV-2 infection [1]. The study is appealing but has several limitations which raise comments and concerns.

The major limitation of the study is that various causes for the deterioration of PD were not excluded. No cerebral imaging had been carried out when PD deteriorated. Mechanical ventilation is no contraindication for cerebral imaging. Missing are also a positron emission tomography (PET) study respectively a dopamin transporter (DAT) scan. No investigations of the cerebro-spinal fluid (CSF) had been carried out to exclude encephalitis or meningitis.

The patient was confused on admission; thus, it is conceivable that there was mismanagement of his medication and that he had developed side effects of overdosages, such as the dopamin (DA) agonist, as he had previously experienced. We should be told for how long the patient was confused already at home and if he was responsible for the management of his daily medication alone or his caregivers.

Missing is the information about the cause of respiratory distress requiring mechanical ventilation. We should be told if respiratory distress resulted from a central nervous system (CNS) cause, from muscular compromise, or from pulmonary infection, in particular COVID-19 pneumonia. Since muscular respiratory distress could be also due to Guillain-Barre syndrome (GBS), increasingly recognised as a complication of

\footnotetext{
* Correspondence: fifigs1@yahoo.de

${ }^{2}$ Klinik Landstrasse, Messerli Institute, Postfach 20, 1180 Vienna, Austria

Full list of author information is available at the end of the article
}

SARS-CoV-2 infections [2], it is crucial that the index patient had undergone appropriate CSF investigations and nerve conduction studies.

A further limitation is that it is not reported how worsening of PD was managed. We should be told if the levodopa carbidopa dosage was increased or if the dosage of the DA-agonist was increased. Since the authors speculate that the infection could be responsible for increased levodopa requirement, it is not comprehensible why he was maintained on his regular dosage [1].

The authors speculate that CNS affection by the virus could be responsible for deterioration of PD but do not provide evidence for this speculation. No evidence was provided that the virus had entered the CNS at all or that there was an immune response mainly affecting the CNS.

We do not agree that 'genetic PD makes the patient vulnerable to immunologically mediated neuronal damage' [1]. This statement is not substantiated by any evidence. Why should immune mechanisms affect patients with genetic and non-genetic PD differentially?

Overall, this interesting case has several limitations which challenge the results and their interpretation. Since the cause of PD deterioration remained undetermined, establishing a causal relation between the SARSCoV-2 infection and the relapse of PD is not justified. Since deterioration of PD can be multicausal, work-up and exclusion of all these differential causes are warranted.

\section{Abbreviations}

CNS: Central nervous system; CSF: Cerebro-spinal fluid; DA: Dopamin; DAT: Dopamin transporter; GBS: Guillain-Barre syndrome; PD: Parkinson's disease; PET: Positron emission tomography

\section{Springer Open}

(c) The Author(s). 2021 Open Access This article is licensed under a Creative Commons Attribution 4.0 International License, which permits use, sharing, adaptation, distribution and reproduction in any medium or format, as long as you give appropriate credit to the original author(s) and the source, provide a link to the Creative Commons licence, and indicate if changes were made. The images or other third party material in this article are included in the article's Creative Commons licence, unless indicated otherwise in a credit line to the material. If material is not included in the article's Creative Commons licence and your intended use is not permitted by statutory regulation or exceeds the permitted use, you will need to obtain permission directly from the copyright holder. To view a copy of this licence, visit http://creativecommons.org/licenses/by/4.0/. 


\section{Acknowledgements}

None

\section{Authors' contributions}

JF: design, literature search, discussion, first draft, critical comments. AF, FS: literature search, discussion, critical comments, final approval. The authors read and approved the final manuscript.

\section{Funding}

None received

\section{Availability of data and materials}

All data reported are available from the corresponding author.

\section{Declarations}

Ethics approval and consent to participate

Not applicable

\section{Consent for publication}

Not applicable

\section{Competing interests}

The authors declare that they have no competing interests.

\section{Author details}

'Disciplina de Neurociencia, Universidade Federal de Sao Paulo/Escola Paulista de Medicina (UNIFESP/EPM), Rua Pedro de Toledo, 697-Vila

Clementino, Sao Paulo 04039-00, Brazil. ${ }^{2}$ Klinik Landstrasse, Messerli Institute, Postfach 20, 1180 Vienna, Austria. ${ }^{3}$ Programa de Estudos Pos-Graduado em Fonoaudiologia, Pontifícia Universidade Catolica de Sao Paulo (PUC-SP), Sao Paulo, Brazil. ${ }^{4}$ Departamento de Fonoaudiologia, Escola Paulista de Medicina/ Universidade Federal de Sao Paulo (EPM/UNIFESP), R. Botucatu, 740-Vila

Clementino, Sao Paulo 04023-062, Brazil.

Received: 3 June 2021 Accepted: 22 June 2021

Published online: 02 July 2021

\section{References}

1. Kamel WA, Ismail II, Ibrahim M, Al-Hashel JY. Unexplained worsening of parkinsonian symptoms in a patient with advanced Parkinson's disease as the sole initial presentation of COVID-19 infection: a case report. Egypt J Neurol Psychiatr Neurosurg. 2021;57(1):60. https://doi.org/10.1186/s41983021-00314-3.

2. Finsterer J, Scorza FA. Guillain-Barre syndrome in 220 patients with COVID19. Egypt J Neurol Psychiatr Neurosurg. 2021;57(1):55. https://doi.org/10.11 86/541983-021-00310-7.

\section{Publisher's Note}

Springer Nature remains neutral with regard to jurisdictional claims in published maps and institutional affiliations.

\section{Submit your manuscript to a SpringerOpen ${ }^{\mathcal{O}}$ journal and benefit from:}

- Convenient online submission

- Rigorous peer review

- Open access: articles freely available online

High visibility within the field

- Retaining the copyright to your article 